\title{
CARBON ABSORPTION CAPABILITY THE WATERS IN THE RUPAT STRAIT OF RIAU PROVINCE
}

\author{
KEMAMPUAN SERAPAN KARBON \\ PERAIRAN SELAT RUPAT PROVINSI RIAU
}

\author{
Siti Ramlah Hasibuan ${ }^{I}$, Rifardi ${ }^{I}$, Sampe Harahap ${ }^{I}$ \\ ${ }^{1}$ Kekhususan Manajemen Sumberdaya Perairan Magister Ilmu Kelautan, Fakultas Perikanan dan \\ Kelautan Universitas Riau, J1. HR Soebrantas Km 12,5 Simpang Baru, Panam - Pekanbaru, Indonesia \\ 28293 \\ Correspondence Author: fardi64@yahoo.co.id
}

\section{$A R T I C L E I N F O$}

Submitted: 16 April 2018

Revised : 15 Mei 2018

Approved: 12 Juni 2018
Kata Kunci :

Serapan $\mathrm{CO}_{2}$

Selat Rupat

TSS, Tercemar

Tidak tercemar

\begin{abstract}
The purpose of this study isto analyze the uptake of carbon in polluted waters and unpolluted based on suspended sediment concentration in Rupat Strait. This study used multivariate statistics of Principle Component Analysis (PCA) and regression analysis to clarity the relationship between suspended sediments and primary productivity with carbon uptake. The results indicate that carbon uptake in polluted waters range from 0.023-0.026 tonC/ $\mathrm{m}^{2} /$ year and unpolluted ranged from 0.034- 0.038 ton $C / \mathrm{m}^{2} /$ year. PCA analysis shows that the two main axes (F1 and F2) can represent $82.26 \%$ of the total diversity of distribution, indicate the contribution of F1 is $70.08 \%$ and $F 2$ is $12.18 \%$. The relationship between total suspended sediment with carbon uptake clearly show if total suspended sediment is higher, the carbon uptake will be lower. On the other hand the relationship between primary productivity and carbon uptake, indicate abundance of primary productivity, the carbon uptake will behigher.
\end{abstract}

Abstrak

Penelitian ini bertujuan untuk menganalisis serapan karbon pada perairan tercemar dan tidak tercemar berdasarkan konsentrasi sedimen tersuspensi di Selat Rupat. Penelitian ini menggunakan statistik multivariate Analisis Komponen Utama (Principle Component Analysis/PCA) dan analisis regresi untuk menunjukkan hubungan sedimen tersuspensi dan produktivitas primer dengan serapan karbon. Hasil penelitian menunjukkan bahwa serapan karbon pada perairan tercemar yaitu berkisar antara 0,023-0,026 tonC $/ \mathrm{m}^{2} /$ tahun dan yang tidak tercemar berkisar antara $0,034-0,038$ tonC $/ \mathrm{m}^{2} /$ tahun. Hasil analisis PCA menunjukkan bahwa dua sumbu utamanya (F1 dan F2) dapat merepresentasikan $82.26 \%$ total keragaman distribusi, yang mana Sumbu F1 menunjukkan kontribusi sebesar 70.08\% dan Sumbu F2 sebesar 12.18\%. Hubungan antara total sedimen tersuspensi dengan serapan karbon jelas menunjukkan jika total sedimen tersuspensi tinggi maka serapan karbon akan semakin rendah, sementara itu hubungan antara produktivitas primer dengan serapan karbon, menunjukkan bahwa produktivitas primer tinggi maka serapan karbonnya juga semakin tinggi 


\section{PENDAHULUAN}

Pemanasan global yang berimplikasi pada terjadinya perubahan iklim, kini semakin mengkhawatirkan. Salah satu penyebabnya adalah aktivitas antropogenik manusia yang dapat menyumbangkan gas karbondioksida $\left(\mathrm{CO}_{2}\right)$. Kegiatan antropogenik manusia yang dapat melepaskan emisi $\mathrm{CO}_{2}$ adalah pembakaran lahan, emisi kendaraan bermotor dan limbah pabrik (Darussalam, 2011).

Menurut Afdal (2007) ekosistem laut mempunyai peranan yang sangat penting dalam mengurangi pemanasan global ataupun peningkatan konsentrasi $\mathrm{CO}_{2}$ di atmosfer. Hal ini karena kemampuan fitoplankton dalam berfotosintesis, dapat dimanfaatkan seoptimal mungkin untuk menyerap $\mathrm{CO}_{2}$ (Sopiah et al., 2013). Salah satu perairan yang dapat dimanfaatkan untuk mengurangi pemanasan global iyalah perairan Selat Rupat Provinsi Riau.

Selat Rupat merupakan selat kecil yang berada di Provinsi Riau, terletak memanjang di bagian Timur Pulau Sumatera yang padat akan aktivitas antropogenik khususnya di Kota Dumai. Banyaknya pengaruh aktivitas antropogenik yang masuk ke perairan Selat Rupat serta besarnya suplai sedimen dari daratan Dumai dan pulau Rupat mengakibatkan degradasi perairan yang menyebabkan abrasi maupun sedimentasi serta peningkatan konsentrasi padatan tersuspensi (TSS) yang melebihi kondisi normal (Rifardi, 2013).

Tingginya konsentrasi sedimen tersuspensi dapat menghambat penetrasi cahaya matahari yang masuk ke dalam perairan sehingga mengganggu proses fotosintesis yang dilakukan oleh fitoplankton maupun mikroalga. Kondisi inilah yang menyebabkan menurunnya produktivitas perairan karena fitoplankton dan alga sebagai produsen primer terganggu perkembangannya. Oleh karena itu peneliti tertarik untuk melakukan penelitian mengenai kemampuan serapan karbon perairan Selat Rupat pada perairan yang tidak tercemar dan perairan tercemar dilihat dari konsentrasi sedimen tersuspensi.

Secara umum penelitian ini bertujuan untuk menganalisis serapan karbon pada perairan tercemar dan belum tercemar berdasarkan konsentrasi sedimen tersuspensi. Secara khusus penelitian ini bertujuan untuk menganalisis hubungan sedimen tersuspensi dan produktivitas primer dengan serapan karbon.

\section{METODE PENELITIAN \\ Lokasi dan Waktu Penelitian}

Penelitian ini dilaksanakan pada bulan September 2017 di perairan Selat Rupat, Provinsi Riau. Bahan dan alat yang digunakan dalam penelitian ini adalah Thermometer, Hand Refractometer, Current Drogue dan Stopwatch, Secchi Disk, Kertas pH Indikator Universal, GPS dan Van dorn sampler.

Metode yang digunakan dalam penelitian ini adalah metode survey. Pengambilan sampel TSS, dan NPP dilakukan di lapangan. Kemudian sampel dianalisis di laboratorium, lalu disajikan dan dibahas secara statistik inferensial.

\section{Penetapan Lokasi Sampling}

Lokasi sampling dibagi menjadi dua area penelitian yang terdiri dari 8 (delapan) Stasiun. Area perairan yang tidak tercemar (Stasiun 1,2, 7 dan 8) dan area perairan yang sudah tercemar (Stasiun 3,4,5 dan 6) yang ditentukan berdasarkan konsentrasi sedimen tersuspensi. Masing-masing posisi Stasiun tersebut ditetapkan dengan menggunakan GPS (Global Positioning System) yang disajikan pada Tabel 1 serta peta titik stasiun penelitian dapat dilihat pada Gambar 1. 
Tabel 1. Penentuan Stasiun Penelitian

\begin{tabular}{|c|c|c|}
\hline St. & \multicolumn{2}{|c|}{ Titik Koordinat } \\
\hline 1 & $\mathrm{~N} \mathrm{01}^{0} 56^{\prime} 14,01^{\prime \prime}$ & E $101^{0} 23^{\prime} 32,20^{\prime \prime}$ \\
\hline 2 & N 01056'36,75" & E $101^{0} 21^{\prime} 09,50^{\prime \prime}$ \\
\hline 3 & $\mathrm{~N} 01^{0} 52^{\prime} 03,41^{\prime \prime}$ & E $101^{0} 22^{\prime} 46,61^{\prime \prime}$ \\
\hline 4 & $\mathrm{~N} 01^{0} 47^{\prime} 41,10^{\prime \prime}$ & E $101^{0} 23^{\prime} 29,62^{\prime \prime}$ \\
\hline 5 & N 01042'18,69" & E $101^{0} 27^{\prime} 29,22^{\prime \prime}$ \\
\hline 6 & $\mathrm{~N} 01^{0} 40^{\prime} 40,50^{\prime \prime}$ & E $101^{0} 32^{\prime} 27,39^{\prime \prime}$ \\
\hline 7 & $\mathrm{~N} 01^{0} 40^{\prime} 56,79^{\prime \prime}$ & E $101^{0} 38^{\prime} 35,86^{\prime \prime}$ \\
\hline 8 & $\mathrm{~N} 01^{\circ} 40^{\prime} 46,01^{\prime \prime}$ & E $101^{\circ} 42^{\prime} 51,20^{\prime \prime}$ \\
\hline
\end{tabular}

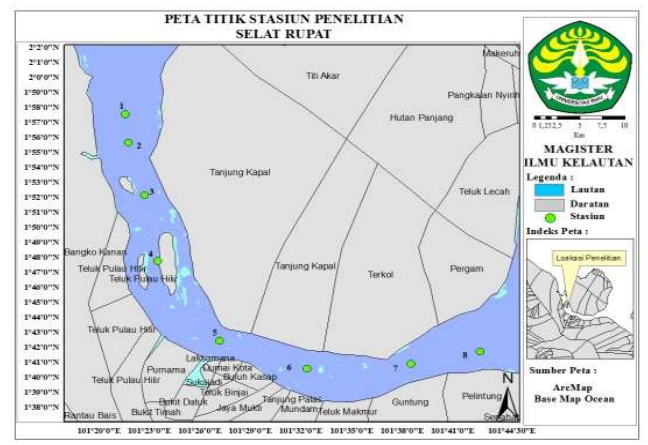

Gambar 1. Peta Titik Stasiun Penelitian

\section{Analisis Sampel}

1. Total Sedimen Tersuspensi

Total Sedimen Tersuspensi (mg/L) dengan mengacu pada rumus Standar Nasional Indonesia (2004) sebagai berikut:

$$
\operatorname{TSS}(\mathrm{mg} / \mathrm{L})=\frac{(\mathrm{A}-\mathrm{B}) \times 1000}{\mathrm{C}}
$$

Keterangan:
$\mathrm{A}=$ Berat kertas saring berisi residu suspense (mg)
$\mathrm{B}=$ Berat kertas saring $(\mathrm{mg})$
$\mathrm{C}=$ Volume sampel (ml)

\section{Produktivitas Primer (NPP)}

Perhitungan NPP yang digunakan adalah berdasarkan Vertical Generalized Productivity Model (Behrenfeld dan Falkowski, 1997) sebagai berikut:

$$
N P P=0.66125 \times P_{\text {opt }}^{B} \times \frac{E_{0}}{E_{0}+4.1} \times C h l \times Z_{e u} \times D L
$$

\section{Dimana :}

Chl = Konsentrasi klorofil- $a$ di permukaan $\left(\mathrm{mg} / \mathrm{m}^{3}\right)$

$\mathrm{DL} \quad=$ Panjang hari (dalam desimal jam)
E0 = PAR (Photosyntetic Available Radiation) permukaan harian (mol quanta $/ \mathrm{m}^{2} /$ hari)

Zeu = Kedalaman zona euphotic $(\mathrm{m})$

$\mathrm{P}^{\mathrm{B}}{ }_{\text {opt }}=$ Laju fiksasi karbon optimum (mgC/mg Chl/hari)

$\mathrm{P}^{\mathrm{B}}$ opt dihitung dari suhu perairan dengan rumus polinomial 7 tingkat menurut Behrenfel dan Falkowski (1997). Perhitungan $\mathrm{P}^{\mathrm{B}}{ }_{\text {opt }}$ terdapat pada rumus berikut :

$$
\begin{aligned}
\mathrm{P}^{\mathrm{B}}{ }_{\text {opt }}= & -3,27 \times 10^{-8} \times \mathrm{T}^{7}+3,4132 \times 10^{-6} \times \\
& \mathrm{T}^{6}-1,348 \times 10^{-4} \times \mathrm{T}^{5}+2,462 \times \\
& 10^{-3} \times \mathrm{T}^{4}-0,0205 \times \mathrm{T}^{3}+0,0617 \\
& \mathrm{X} \mathrm{T}^{2}+0,2749 \times \mathrm{T}+1,2956
\end{aligned}
$$

3. Serapan Karbon

Untuk menghitung potensi serapan karbon di perairan Selat Rupat, dapat dihitung dengan mengacu pada Rifardi (2011) dengan rumus sebagai berikut :

$$
\mathrm{SC}=\operatorname{Luas} \times\left(\mathrm{BM} \mathrm{CO}_{2} / \mathrm{BM} \mathrm{C} \times \mathrm{NPP}^{\mathrm{N}}\right)
$$

Keterangan :

Luas $=$ Luas Daerah Penelitian $\left(\mathrm{m}^{2}\right)$

$\mathrm{BM} \mathrm{CO}_{2}=44$

$\mathrm{BMC}=12$

$\mathrm{NPP}=$ Produktivitas Primer Bersih ( $\mathrm{gC} / \mathrm{m}^{2} /$ tahun)

\section{Analisis Data}

1. Analisis Karakteristik Lingkungan Perairan Selat Rupat digunakan pendekatan statistik multivariat Analisis Komponen Utama (Principle Component Analysis/PCA) (Legendre, 1983 dan Bengen, 1998).

2. Analisis uji perbedaan serapan karbon antara perairan tidak tercemar dan yang sudah tercemar dengan menggunakan uji t pada $\alpha=0,05$.

3. Analisis hubungan antara sedimen tersuspensi dan produktivitas primer (NPP) terhadap serapan karbon digunakan analisis regresi dan uji t. Selanjutnya untuk menjelaskan hasil dari analisis data dengan statistik inferensial tersebut mengacu pada Tanjung (2014). 


\section{HASIL DAN PEMBAHASAN Total Sedimen Tersuspensi}

Nilai sedimen tersuspensi yang diperoleh selama penelitian di perairan Selat Rupat dapat dilihat pada Tabel 2.

Tabel 2. Sedimen Tersuspensi di Perairan Selat

\begin{tabular}{ccc}
\multicolumn{3}{c}{ Rupat } \\
\hline Stasiun & TSS & Keterangan \\
\hline 1 & 17 & Tidak Tercemar \\
2 & 18 & Tidak Tercemar \\
3 & 122 & Tercemar \\
4 & 117 & Tercemar \\
5 & 115 & Tercemar \\
6 & 125 & Tercemar \\
7 & 17 & Tidak Tercemar \\
8 & 16 & Tidak Tercemar
\end{tabular}

Sumber : Pribadi, 2017

Dari tabel tersebut dapat diketahui bahwa sedimen tersuspensi pada perairan yang tercemar sudah melebihi baku mutu dan yang tidak tercemar belum melebihi baku mutu. Hal tersebut diduga TSS berasal dari abrasi pantai, muara sungai serta stasiun sampling yang berdekatan dengan kawasan yang padat aktivitas seperti pengerukan pasir, industri minyak $\mathrm{CPO}$, pelabuhan Dumai dan kilang minyak PT. PERTAMINA R II Dumai. Sedangkan pada perairan yang tidak tercemar sedimen tersuspensi diduga berasal dari mangrove sehingga sedimen tersuspensi rendah. Hal ini sesuai dengan pendapat Arvianto et al., (2016), dimana sumber sedimen tersuspensi berasal dari hasil erosi daerah atas (up land), hasil erosi dasar sungai, hasil degradasi makhluk hidup, serta limbah industri dan rumah tangga.

\section{Produktivitas Primer (NPP)}

Produktivitas primer adalah jumlah bahan organik yang dihasilkan oleh organisme autotrof. Nilai produktivitas primer (NPP) yang diperoleh selama penelitian di perairan Selat Rupat dapat dilihat pada Tabel 3.
Tabel 3. Nilai Produktivitas Primer di Perairan Selat Rupat

\begin{tabular}{cc}
\hline Stasiun & Produktivitas Primer (mg/L) \\
\hline 1 & 94.9 \\
2 & 91.98 \\
3 & 70.08 \\
4 & 62.05 \\
5 & 66.43 \\
6 & 63.51 \\
7 & 98.55 \\
8 & 103.66 \\
Sumber : Pribadi, 2017
\end{tabular}

Berdasarkan tabel tersebut diketahui bahwa NPP perairan yang sudah tercemar lebih rendah dibandingkan perairan yang tidak tercemar. Perbedaan produktivitas primer pada perairan yang sudah tercemar dan yang tidak tercemar pada saat penelitian di perairan selat Rupat dipengaruhi oleh nutrien berupa nitrat dan fosfat serta konsentrasi klorofil-a yang lebih tinggi pada perairan yang tidak tercemar disbanding perairan tercemar. Hal ini sesuai dengan pendapat (Chen, 2017), dimana kandungan klorofil-a dapat digunakan sebagai ukuran banyaknya fitoplaknton pada suatu perairan tertentu dan dapat digunakan sebagai petunjuk produktivitas perairan. Unsur hara merupakan faktor yang memberikan pengaruh terhadap tinggi rendahnya produktivitas primer perairan (Irawati et al., 2013).

Serapan Karbon

Serapan karbon yang di peroleh selama penelitian di perairan Selat Rupat dapat dilihat pada Tabel 5.

Tabel 5. Serapan Karbon di Perairan Selat Rupat

\begin{tabular}{cc}
\hline Stasiun & Serapan Karbon $\left(\right.$ tonC $\left./ \mathrm{m}^{2} / \mathrm{thn}\right)$ \\
\hline 1 & 0,035 \\
2 & 0,034 \\
3 & 0,026 \\
4 & 0,023 \\
5 & 0,024 \\
6 & 0,023 \\
7 & 0,036 \\
8 & 0,038 \\
\hline Sumber : Pribadi, 2017
\end{tabular}

Berdasarkan tabel tersebut dapat diketahui bahwa serapan karbon di 
perairan Selat Rupat pada perairan tercemar lebih rendah dibanding perairan yang tidak tercemar. Perbedaan serapan karbon di perairan dipengaruhi oleh konsentrasi sedimen tersuspensi dan produktivitas primer (NPP). Hal ini sesuai dengan pendapat Fitriya et al., (2011), dimana penyerapan $\mathrm{CO}_{2}$ oleh laut tergantung produktivitas primer oleh fitoplankton laut karena fitoplankton ikut memandu distribusi regional dan musiman dari fluks $\mathrm{CO}_{2}$. Sehingga apabila sedimen tersuspensi pada perairan tinggi maka akan mempengaruhi proses fotosintesis dan akan berdampak terhadap serapan karbon di perairan.

Karakteristik Lingkungan Perairan Selat Rupat

Hasil analisis PCA yang dilakukan untuk mengkaji variasi karakteristik lingkungan perairan Selat Rupat ditiap stasiunnya dapat dilihat pada Gambar 1.

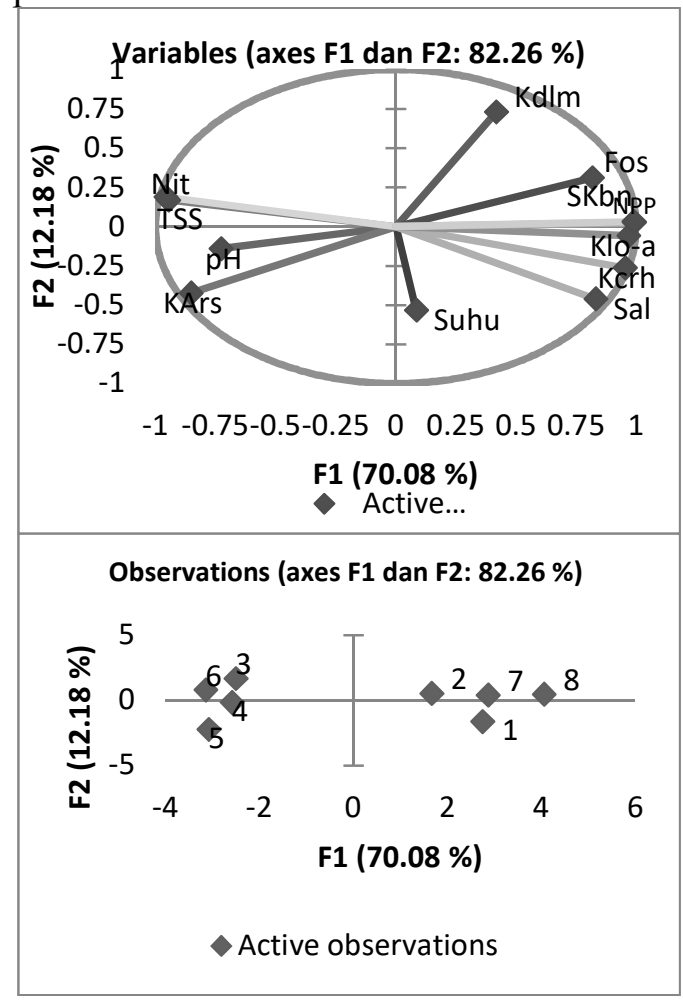

Gambar 1. Karakteristik Lingkungan Perairan Selat Rupat

Sumber : Pribadi, 2017
Berdasarkan gambar tersebut dapat diketahui bahwa keragaman pada Sumbu 1 dicirikan oleh fosfat, NPP, serapan karbon, kecerahan, salinitas, $\mathrm{pH}$, kecepatan arus, TSS dan nitrat; sedangkan Sumbu 2 dicirikan oleh kedalaman dan suhu perairan. Kemudian, untuk sebaran stasiun parameter lingkungan perairan berdasarkan stasiun pengamatannya membentuk 4 kelompok. Kelompok pertama terdiri atas fosfat, nilai produktivitas primer, serapan karbon, kecerahan dan salinitas yang tinggi pada Stasiun 7 dan 8.

\section{Hubungan Kondisi Perairan dengan Serapan Karbon}

Hasil uji regresi antara sedimen tersuspensi dan serapan karbon di perairan Selat Rupat dapat dilihat pada Gambar 1.

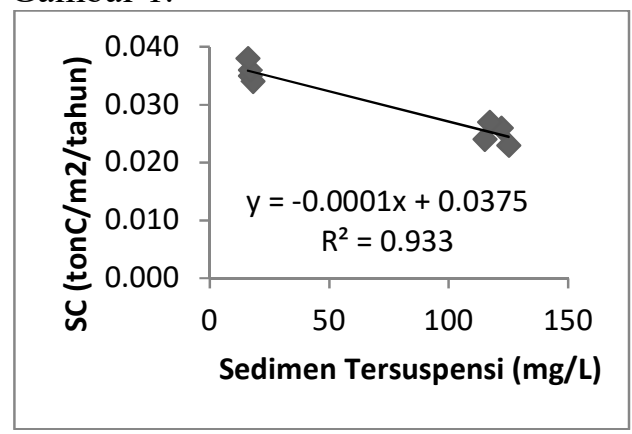

Gambar 2. Grafik Hubungan TSS dan Serapan Karbon (SC)

Berdasarkan gambar tersebut dapat dilihat bahwa semakin tinggi konsentrasi TSS akan menyebabkan semakin rendah serapan karbon di perairan Selat Rupat. Hal ini karena tingginya konsentrasi sedimen tersuspensi menyebabkan penurunan produktivitas primer, karena adanya penutupan (block) penetrasi cahaya matahari ke dalam air dan menggangu proses fotosintesis sehingga akan mempengaruhi fitoplankton dalam menyerap karbon. Hal ini sesuai dengan pendapat Duan et al. (2015) yang menyatakan bahwa padatan tersuspensi yang tinggi dapat secara signifikan mengurangi atau membatasi penetrasi cahaya yang masuk ke dalam air dan 
akan memberikan dampak terhadap produktivitas primer.

Hasil uji regresi antara produktivitas primer dan serapan karbon di perairan Selat Rupat dapat dilihat pada Gambar 3.

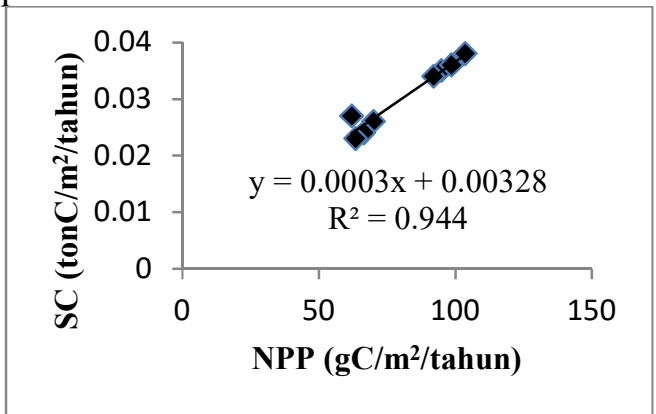

Gambar 3. Grafik Hubungan Produktivitas Primer dan Serapan Karbon

Dari gambar tersebut dapat diketahui bahwa semakin tinggi produktivitas primer maka serapan karbon di perairan Selat Rupat juga akan semakin tinggi. Hal ini sesuai dengan pendapat Chen (2017), dimana produktivitas primer merupakan laju produksi karbon organik (karbohidrat) per satuan waktu dan volume melalui proses fotosintesis yang dilakukan oleh organisme tumbuhan hijau, sehingga apabila konsentrasi sedimen tersuspensi tinggi maka proses fotosintesis juga akan terganggu.

Hasil penelitian ini sesuai dengan hasil penelitian yang dilakukan oleh Rifardi (2011) di Perairan Estuaria Bagan bagian Selatan, dimana apabila kualitas air dalam kondisi baik (normal) maka serapan karbon akan tinggi, karena kualitas air sangat menentukan produktivitas primer perairan dan produktivitas primer mempunyai peran penting dalam siklus karbon dan rantai makanan serta perannya sebagai pemasok kandungan oksigen terlarut di perairan (Zang et al., 2014).

\section{KESIMPULAN}

Serapan karbon pada perairan yang tercemar yaitu berkisar 0,023-0,026 tonC $/ \mathrm{m}^{2} /$ tahun, sedangkan pada perairan yang tidak tercemar mampu menyerap karbon berkisar 0,034-0,038 tonC $/ \mathrm{m}^{2} /$ tahun, hubungan antara sedimen tersuspensi dan serapan karbon yaitu semakin tinggi sedimen tersuspensi di perairan Selat Rupat, maka serapan karbon semakin rendah, hubungan antara produktivitas primer terhadap serapan karbon memiliki hubungan yang kuat, dimana semakin tinggi produktivitas primer maka serapan karbon semakin tinggi.

\section{SARAN}

Berdasarkan hasil penelitian tentang kemampuan serapan karbon perairan Selat Rupat , penulis menyarankan untuk melakukan penelitian selanjutnya yaitu tentang koefisien serapan karbon di perairan Selat Rupat, sehingga nilai koefisien tersebut dapat digunakan di perairan yang lain.

\section{UCAPAN TERIMA KASIH}

Penulis mengucapkan terima kasih banyak kepada Prof. Dr. Ir. Rifardi, M.Sc dan Dr. Ir. Sampe Harahap, MS atas bimbingan dan motivasi yang diberikan dalam menyelesaikan hasil penelitian ini serta orang tua, abang, kakak dan semua pihak yang telah banyak membantu penulis dalam menyusun hasil penelitian ini.

\section{DAFTAR ACUAN}

Afdal. 2007. Siklus Karbon dan Karbodioksida di Atmosfer dan Samudera. Oseana 32 (2): 2941.

Arvianto, S.E, A. Satriadi dan G. Handoyo. 2016. Pengaruh Arus Terhadap Sebaran Sedimen Tersuspensi di Muara Sungai 
Silugonggo Kabupaten Pati. Jurnal Oseanografi. 5(1): 116 125.

Behrenfeld MJ, Falkowski PG. 1997. A comumers guide to primary productivity models. Limnol. Oceanogr. 42: 1479-1491.

Bengen, D. G. 1998. Sinopsis Analisis Statistik

Multivariabel/Multidimensi.

Program Pascasarjana. IPB.

Bogor.

BPTPM (Badan Pelayanan Terpadu dan Penanaman Modal Kota Dumai). 2012. Potensi dan peluang investasi Kota Dumai. Dumai (ID): Dumai Indonesia.

Chen H. 2017. Simplified, Rapid, and Inexpensive Estimation Of Water Primaryproductivity Based On Chlorophyll Fluorescence Parameter Fo. Journal Of Plant Physiology, $211: 128-135$.

Darussalam, D. 2011. Pendugaan Potensi Serapan Karbon Pada Tegakan Pinus di KPH Cianjur Perum Perhutani Unit III Jawa Barat dan Banten (skripsi). Institut Pertanian Bogor. Bogor (tidak diterbitkan).

Duan, W.L., B. He, K. Takara, P.P. Luo, D. Nover dan M.C. Hu. 2015. Modeling Suspended Sediment Sources and Transport in The Ishikari River Basin, Japan, Using SPARROW. Hydrol. Earth Syst. SCI. 19: 1293-1306.

Fitriya N., H. Surbakti dan R. Aryawati. 2011. Pola Sebaran Fitoplankton Serta Klorofil-A pada Bulan November di Perairan Tambelan, Laut Natuna. Maspari Journal 03 (1): 01-08.

Legendre, L. dan P. Legendre. 1983. Numerical Ecology. Elsevier Scientific Publishing Company. $419 \mathrm{p}$.
Rifardi. 2011. Lingkungan Pengendapan Perairan Selatan Estuaria Bagan dan Sekitarnya Pantai Timur Sumatera Indonesia. Jurnal Ilmu Lingkungan.

Rifardi. 2013. Analisis Degradasi Sumberdaya Perairan Selat Rupat Pantai Timur Sumatera Berdasarkan Aspek Sedimentasi Sebagai Dasar dalam Perencanaan Pembangunan dan Pengelolaan Wilayah Pesisir Kota Dumai Provinsi Riau. Penelitian Fundamental Universitas Riau.

Sopiah N., A. Mulyanto dan S. Sehabudin. 2013. Pengaruh Kelimpahan Sel Mikroalgae Air Tawar (Chlorella sp.) Terhadap Penambatan Karbondioksida. Jurnal Teknologi Lingkungan. 14(1): $1-6$.

Standar Nasional Indonesia (SNI). 2004. Air dan Air Limbah - Bagian 3: Cara Uji Padatan Tersuspensi Total (TSS) Secara Gravimetri.

Tanjung, A. 2014. Rancangan Percobaan. Tantaramesta Asosiasi Direktori Indonesia, Bandung. 127 hal.

Zhang Y, Li Zhang dan W.J. Mitscha. 2014. Predicting River Aquatic Productivity and Dissolved Oxygen Before and After Dam Removal. Ecological Engineering, $72: 125-137$.

\section{E-mail :}

sitiramlahmsp@gmail.com fardi64@yahoo.co.id

harahap@yahoo.com 